\title{
POLITIK KEBUDAYAAN DALAM NOVEL SINDEN KARYA PURWADMADI ADMADIPURWA: KAJIAN SEMIOTIKA ROLAND BARTHES
}

\section{CULTURAL POLITICS IN THE SINDEN NOVEL BY PURWADMADI ADMADIPURWA: ROLAND BARTHES SEMIOTIC STUDIES}

\author{
Nuri Dwi Vindriana ${ }^{1}$, Sunarti Mustamar ${ }^{2 *}$, Sri Mariati ${ }^{3}$ \\ ${ }^{1}$ Alumnus Fakultas Ilmu Budaya, Universitas Jember \\ ${ }^{2,3}$ Fakultas Ilmu Budaya, Universitas Jember \\ *Corresponding Author: sunartimustamar1959@gmail.com
}

Informasi Artikel:

Dikirim: 8/2/2018; Direvisi: 4/3/2018; Diterima: 14/4/2018

\begin{abstract}
This study relies on cultural political issues in the Sinden novel to be analyzed using the concept of Roland Barthes mythology. The mythology looks at the form of speech, including a literary work that reflects and reduces social discourse, cultural, ideological and historical. The method used in this research is a qualitative research method. The analysis has two stages of the sign system. The first system is the sign of denotative sign reading that takes the structural data covering themes, characters, conflicts, and settings that will produce signs. The results mark the first sign of the system as a new marker for a myth reading on both sign system. The reading of the myth in the Sinden novel generates political discourse cultures that reflect events in Indonesia with 1960s background. This study aims to describe the cultural issues covered by political interests and reveal the impact of cultural-political events experienced by the grassroots and increase appreciation of the reader in understanding the Sinden novel.
\end{abstract}

Keywords: art event 1960 in Indonesia, cultural politics, Roland Barthes's mythologies, semiotic, the Sinden novel

\section{Abstrak}

Penelitian ini bertumpu pada permasalahan politik kebudayaan dalam novel Sinden yang akan dikaji menggunakan konsep mitologi Roland Barthes. Mitologi memandang bentuk ujaran termasuk suatu karya sastra yang merefleksikan dan mereduksi wacana sosial, kultural, ideologis dan historis. Metode yang digunakan adalah metode penelitian kualitatif. Analisis yang dilakukan mempunyai dua tahapan sistem tanda. Sistem tanda pertama adalah pembacaan tanda secara denotatif yang mengambil data struktural meliputi tema, tokoh, konflik dan latar akan menghasilkan tanda-tanda. Hasil tanda pada sistem tanda pertama sebagai penanda baru untuk melakukan pembacaan mitos pada sistem tanda kedua. Pembacaan mitos pada novel Sinden menghasilkan wacana politik kebudayaan yang merefleksikan peristiwa-peristiwa di Indonesia dengan latar 
Politik Kebudayaan dalam Novel Sinden Karya Purwadmadi Admadipurwa Kajian Semiotika Roland Barthes (Nuri Dwi Vindriana, Sunarti Mustamar, Sri Mariati)

waktu 1960-an. Penelitian ini bertujuan untuk mendeskripsikan persoalan budaya yang diliputi oleh kepentingan politik dan mengungkapkan dampak peristiwa politik kebudayaan yang dialami oleh masyarakat bawah dan menambah apresiasi pembaca dalam memahami novel Sinden.

Kata Kunci: mitologi Roland Barthes, novel Sinden, peristiwa kesenian 1960 di Indonesia, politik kebudayaan, semiotika.

\section{PENDAHULUAN}

Karya sastra dikatakan sebagai objek manusiawi, fakta kemanusiaan, atau fakta kultural. ${ }^{1}$ Hal tersebut menjadi wajar karena karya sastra seringkali merekam segala kompleksitas kehidupan. Mukarovsky (dalam Faruk, 2012:17) menyebutkan keberadaan karya sastra sebagai fakta kemanusiaan bersifat semiotik mempunyai ciri khas yang perlu diketahui. Gambaran tersebut terbangun oleh gagasan atau ide yang dibentuk unsur-unsur intrinsik yang dikemas dengan penuh estetika menjadi sebuah karya sastra, namun bukan hanya keindahan melainkan terdapat realitas di dalamnya. Kesatuan unsur-unsur intrinsik tersebut menjadi penting untuk membangun dan menguatkan cerita menjadi lebih hidup. Pembaca akan mudah menangkap dan memahami keutuhan realita melului tanda-tanda yang dikonstruksi dalam cerita. Kesatuan cerita tersebut tidak hanya membangun tanda namun memiliki makna yang terkandung di dalamnya.

Penelitian ini akan mengungkapkan kondisi sosial, politik, dan budaya dalam novel Sinden karya Purwadmadi Admadipurwa. Novel tersebut memperkenalkan budaya Jawa yang meliputi kehidupan masyarakat Jawa dan kesenian tradisional. Purwadmadi lahir di Gunung Kidul, suatu tempat yang didukung oleh fisiografi dan masyarakat yang masih mempertahankan budaya luhur nenek moyang. Purwadmadi yang dikenal dengan panggilan Pur adalah seorang novelis dan jurnalis. Novel ini mempunyai cerita yang kompleks dengan konflik terjadinya politik kebudayaan pada suatu daerah yang menjadi dampak dari kondisi politik negara pada masa itu.

Novel Sinden menceritakan cara hidup, cara berpikir, dan pandangan pemikiran masyarakat bawah yang menerima cara berpikir dan gaya hidup dari kelompok elit yang berkuasa dan mengeksploitasi mereka. Novel Sinden dibuka dengan prolog berita seorang penyair yang hilang. Desa Sumberwungu merupakan tanah kelahiran penyair tersebut, setelah mendengar berita hilangnya Tuwuh, masyarakat desa menjadi resah. Berita tersebut juga memberi pengetahuan kepada masyarakat desa bahwa Tuwuh adalah orang berpengaruh di Yogyakarta. Berita hilangnya Tuwuh terjadi ketika di kota sedang terjadi ketegangan antara mahasiswa dan aparat keamanan. Prolog tersebut menjadi pengantar dari pascaperistiwa isi cerita novel ini. Bagian 1 sampai dengan bagian 14 merupakan rentetan

\footnotetext{
${ }^{1}$ Karya sastra dikatakan sebagai objek manusiawi, fakta kemanusiaan, atau fakta kultural, sebab merupakan hasil ciptaan manusia. Sebagai fakta kemanusiaan, karya sastra merupakan ekspresi dari kebutuhan tertentu manusia.
} 
cerita orang tua Tuwuh, sebelum Tuwuh lahir di desa Sumberwungu. Desa tersebut dikenal telah menciptakan sinden-sinden terkenal dan mengalami dampak politik kebudayaan.

Novel Sinden mengisahkan Tumi atau Nyai Renggomanis (nama setelah menjadi Sinden kondang) menjadi seorang Sinden. Kisah tersebut tidak hanya menceritakan perjalanan Tumi sampai berhasil menjadi seorang sinden tetapi cerita tersebut mampu memaparkan kehidupan yang lebih luas.

Ihwal partai politik, beberapa penanda seperti "di seputar balai desa ini banyak terpampang gambar-gambar raksasa lambang partai. Gambar dibuat di atas anyaman bambu dengan cat putih dan hitam" (Sinden:37). Pada gambar tersirat bahwa novel tersebut memiliki kemungkinan untuk menggambarkan Partai Komunis Indonesia. Kisah kemunculan partai berhubungan dengan politik kebudayaan yang sedang terjadi di Indonesia pada masa peralihan pemerintahan orde lama ke masa pemerintahan orde baru. Politik kebudayaan yang terjadi dalam novel Sinden berlatar peristiwa sekitar tahun 60-an.

Perihal partai dibawa pertama kali oleh Mangundarmo, seorang penggawa kantor desa kepercayaan Poncodriyo yang tidak dijelaskan asalnya. Mangundarmo mempunyai kedekatan dengan kelompok ketoprak Misuwur Budaya. Mereka mengadakan ketoprak dengan gairah seni pertunjukan rakyat bertema antifeodalisme. Pertunjukan tersebut tidak hanya menghibur tetapi berubah menjadi arena propaganda politik dengan ideologi suatu golongan.

Tumi tidak memihak suatu golongan. Nyai Estu, guru sinden Tumi, mengajarkan kesenian adiluhung. ${ }^{2}$ Mereka berdua tidak sengaja masuk ke suatu golongan yang mempunyai kesamaan persepsi membangun satu ideologi, meskipun pada awalnya mereka tidak memihak suatu golongan. Tumi, Nyai Estu, dan beberapa warga desa masuk ke dalam suatu kelompok yang kontra terhadap Poncodriyo, sebelumnya mereka tidak pernah muncul di dalam persoalan Desa Sumberwungu. Kita dapat memahami dengan melihat akibat dari peristiwa tersebut karena Tumi dan warga desa tidak mengetahui persis permasalahannya. Mereka mengikuti alur peristiwa yang secara tidak langsung mereka masuk ke dalam perangkap sejarah.

Sebuah saluran berita nasional memberitakan bahwa telah terjadi perubahan besar yaitu sebuah pemerintahan baru. Hal tersebut mengantar pemahaman warga atas apa yang sedang terjadi. Sejak awal novel Sinden memperkenalkan nama Tuwuh sebagai penyair yang hilang. Alur cerita menggunakan alur mundur jika diruntut hilangnya Tuwuh dan tragedi bentrok mahasiswa dengan aparat keamanan, terjadi 20-30 tahun setelah propaganda politik kesenian rakyat di Desa Sumberwungu terjadi. Politik kebudayaan tersebut ditunjukkan oleh dua lembaga kesenian yang mempunyai perbedaan ideologi, yaitu Lembaga Kebudayaan Rakyat (Lekra) dengan Manifest Kebudayaan (Manikebu).

Novel Sinden menjadi menarik untuk diteliti karena di dalamnya terdapat kompleksitas cerita yang dapat mencakup budaya masyarakat Jawa, perkembangan seni pertunjukan ketoprak dan peristiwa politik yang terjadi di sekitarnya. Pemikiran Gramsci

\footnotetext{
${ }^{2}$ Kesenian adiluhung atau "seni untuk seni" merupakan ideologi Manifestasi kebudayaan yang memperlakukan kesenian secara murni (dalam ceramah Gunawan Muhammad-Sastra, Politik, Manikebu)
} 
Politik Kebudayaan dalam Novel Sinden Karya Purwadmadi Admadipurwa Kajian Semiotika Roland Barthes (Nuri Dwi Vindriana, Sunarti Mustamar, Sri Mariati)

tentang hegemoni, kekuasaan yang digerakkan oleh kepemimpinan moral-intelektual, menempatkan budaya secara dinamis sebagai aparatus hegemonik yang melakukan proses seleksi artikulasi dan inkorporasi terhadap bermacam teks, aktor, nilai, praktik, dan kepentingan yang berlangsung dalam masyarakat. Tujuannya adalah menciptakan konsensus sebagai basis untuk membuat blok historis yang mempertemukan bermacam kepentingan politik kelas demi terwujudnya kepemimpinan yang dominan-efektif (Setiawan, 2014).

Perbedaan ideologi pada dua golongan ketoprak yang digunakan sebagai media mencari massa untuk kepentingan politik. Teori sastra perlu melihat cara beroperasinya kepentingan politik melalui struktur naratif, bukan sebagai dogma, melainkan sebagai praktik representasi yang menjadikannya tampak alamiah. Roland Barthes mampu memunculkan perspektif baru terkait cara baca struktur naratif sastra yang berjalin-kelindan dengan kehidupan dan permasalahan dalam masyarakat (Setiawan, 2014).

Pembacaan tanda pada novel ini akan dilakukan dengan cara kerja mitologi Barthes. Teori semiotika Barthes merupakan pengembangan dari teori Ferdinand de Saussure yaitu semiologi. Semiologi berasal dari kata semion yang berarti tanda. Barthes menyebut pesanpesan sebagai mitos. Cara kerja mitos dilakukan dengan menggunakan dua tahapan yaitu menguraikan tanda secara semiologi dan menguraikan tanda secara mitologi. Semiologi tidak berurusan dengan isi melainkan dengan bentuk yang membuat suara, imaji, gerak, dan seterusnya yang berfungsi sebagai tanda, sedangkan Mitologi terdiri atas semiologi dan ideologi. Semiologi sebagai formal science dan ideologi sebagai historical science. Mitologi mempelajari tentang ide-ide dalam suatu bentuk (Iswidayati, 2006). Mitos tersebut kemudian memunculkan suatu hal alamiah yang menghasilkan motivasi dari sebuah karya sastra.

\section{METODE PENELITIAN}

Penelitian ini menggunakan metode kualitatif yang menitikberatkan segi alamiah dan karakter yang terdapat dalam data dengan menggunakan pendekatan struktural dan semiotika. Paradigma metodologis penelitian yang menjadi tumpuan semiotik budaya adalah paradigma kualitatif, penelitian artefak atau teks yang dapat didukung dengan paradigma partisipatoris/kuantitatif. Namun, yang menjadi paradigma pokok adalah kualitatif (Hoed, 2014:19). Teori struktural digunakan sebagai cara menganalisis unsurunsur karya sastra. Keterkaitan antarunsur dapat menggambarkan dan menjelaskan tentang peranan tema, tokoh, latar dan konflik. Menurut Pradopo (dalam Jabrohim, 2003:94) teori yang sesuai untuk mendampingi strukturalisme adalah teori semiotik, yaitu untuk dapat memahami sastra sepenuhnya sebagai struktur, haruslah diinsafi ciri khas sastra sebagai tanda (sign). Tanda itu baru bermakna apabila diberi makna oleh pembaca berdasarkan konvensi yang berhubungan dengannya.

Penelitian ini akan mendeskripsikan konflik budaya yang terjadi dalam novel Sinden. Konflik antargolongan kebudayaan yang dipengaruhi oleh peristiwa politik di suatu daerah yang tidak disadari merupakan peristiwa nasional. Hal tersebut dapat dilakukan 
dengan metedologi dan pendekatan-pendekatan untuk mengungkap segi pemaknaan pada novel tersebut.

\section{HASIL DAN PEMBAHASAN Analisis Struktural}

Unsur intrinsik dalam karya sastra membangun sebuah karya sastra menjadi hidup. Tema, tokoh, konflik, latar, dan unsur-unsur lainnya membentuk sebuah karya sastra menjadi kompleks dengan menghadirkan beragam makna tentang permasalahan sosial, ekonomi, politik, dan kultural dalam masyarakat. Membaca sebuah karya sastra naratif, hal pertama yang harus dipahami adalah kesadaran struktural. Artinya, sebuah karya sastra tidak lepas dari keterkaitan unsur-unsur atau kerangka yang membangun sebuah karya sastra (Faruk, 2012:155-156; Setiawan, 2014:30).

Analisis struktural merupakan pembacaan makna tanda pada sistem tanda pertama. Unsur-unsur intrinsik yang terdapat pada unit naratif novel Sinden karya Purwadmadi Admadipurwa memiliki makna denotatif/tanda global. Unsur-unsur intrinsik yang dianalisis meliputi: tema, tokoh, konflik, dan latar.

\section{Tema}

Tema adalah unsur intrinsik terpenting dalam karya sastra karena merupakan ide dasar dalam sebuah karya sastra. Pada analisis ini, tema adalah submitos dari elemen proses penandaan yang memiliki makna denotatif. Tema pada novel Sinden karya Purwadmadi Admadipurwa dibagi menjadi dua, yaitu tema mayor dan tema minor.

Tema mayor adalah makna pokok cerita yang menjadi dasar atau gagasan umum suatu karya sastra (Nurgiyantoro, 2005:82-83). Tema mayor pada novel Sinden karya Purwadmadi Admadipurwa yaitu "dengan kegigihan, seorang wanita berhasil menjadi sinden walaupun dihadapkan dengan propaganda kesenian" Tema tersebut menjadi tanda dari pembacaan sistem pertama atau makna denotatif.

Tema minor merupakan makna-makna tambahan pada suatu karya sastra (Nurgiyantoro, 2005:82 - 83). Tema minor pada novel sinden yaitu: "Keresahan dan ketidakpahaman masyarakat terhadap simpang siur permasalahan yang terjadi” dan "Orang yang melanggar hukum akan diadili”. Hal tersebut dapat dilihat pada data berikut.

"Ketenaran sinden bukan didasarkan pada kemampuan tampil sebagai penggoda. Derajat tertinggi sinden apabila dapat dicapai tataran sebagai sinden sejati.Sinden demikian adalah sinden yang mampu menegakkan prinsip hidup.”(Sinden:100).

Sinden sejati memiliki nilai luhur yang tinggi, berbeda dengan seorang sinden biasa. Suara merdu tidak dapat keluar dari materi yang dikuasi oleh seorang sinden tetapi dari jiwa untuk mengolah pikir dan menguasai diri dalam pergaulan sehari-hari.Tantangan untuk menjadi sinden sejati cukup banyak karena harus berhadapan dengan beberapa orang yang mempunyai kepentingan untuk propaganda lewat kesenian. Tema tersebut yang dijadikan tolok ukur untuk analisis structural berikutnya. 
Politik Kebudayaan dalam Novel Sinden Karya Purwadmadi Admadipurwa Kajian Semiotika Roland Barthes (Nuri Dwi Vindriana, Sunarti Mustamar, Sri Mariati)

Tema minor novel Sinden adalah "Keresahan dan ketidakpahaman masyarakat terhadap peristiwa yang simpang siur di masyarakat". Hal tersebut tercermin pada data berikut.

"Puncaknya dialami langsung oleh Nyai Estu, yaitu ketika kekuasaan Poncodriyo mulai digunakan untuk memaksa warga. Perkara hilangnya Rudito, penangkapan Karto dan raibnya Gendon seakan berlalu begitu saja."(Sinden:271).

Nyai Estu merupakan salah satu warga yang dapat membaca kejadian politik yang menimpa desa Sumberwungu. Golongan yang dulunya berkuasa memegang kendali pemerintahan di desa Sumberwungu telah ditangkap. Orang- orang yang terlibat dalam rencana merebut kekuasaan di desa Sumberwungu menjadi sorotan golongan orang-orang yang ditahan seperti: Lurah Ponco,Mangondarmo dan Nyai Suparni. Peristiwa tersebut melukiskan adanya kekacauan karena perebutan kekuasaan di desa Sumberwungu.

\section{Tokoh}

Tokoh merupakan salah satu unsur intrinsik yang membentuk struktur dalam karya sastra. Tokoh adalah pelukisan gambaran yang jelas tentang seseorang yang ditampilkan dalam sebuah cerita (Nurgiyantoro, 2005:165). Pada analisis ini, tokoh adalah submitos dari elemen proses penandaan yang menghasilkan makna denotatif. Tokoh-tokoh dalam novel Sinden memiliki karakternya masing-masing yang dipengaruhi oleh konsep sebagai perantara ideologi. Tokoh-tokoh tersebut sebagai berikut.

Tumi. Tumi adalah seorang gadis yang sederhana namun mempunyai kegigihan yang kuat untuk mencapai cita-citanya. Tumi merupakan tokoh utama dalam novel ini karena porsinya dalam pembawa cerita dari awal sampai akhir cerita sangat penting. Secara denotatif, Tumi mewakili tokoh masyarakat biasa yang memiliki pemikiran dan ketulusan tanpa suatu kepentingan golongan tertentu. Hal tersebut terlihat pada data berikut.

"Tumi adalah sinden Sumberwungu yang dikenal luas. Suara emasnya, dirindukan dimana-mana. Namun Tumi tetap bersahaja. Kain jaritnya hanya kain batik cap, bukan batik tulis. Kebayanya hanya kain lurik... perhiasan emas yang dikenakannya pun dengan ukuran seperlunya" (Sinden:299).

Tumi seorang wanita yang memiliki kegigihan untuk mencapai cita-citanya menjadi seorang sinden. Keberhasilannya menjadi seorang sinden ternama terlihat dari popularitas dan pancaran jiwa seorang sinden sejati dalam dirinya. Hal tersebut yang menunjukkan tanda sosok peribadi wanita biasa yang memiliki ketulusan tanpa berpihak pada golongan tertentu.

Rudito. Rudito adalah seorang laki-laki yang berwatak keras. Dia tumbuh besar secara berkecukupan. Segala sesuatu yang diinginkan Rudito harus segera terealisasi. Dia adalah anak Poncodriyo, Lurah Desa Sumberwungu. Secara denotatif, Rudito mewakili cerminan masyarakat biasa yang hanya memikirkan keinginannya sendiri. Hal tersebut terlihat pada data berikut. 
"Rudito telah tumbuh menjadi pemuda yang menyukai kesenangan lain... Rudito dikenal sebagai pemuda yang serba susah. Kesukaannya berjudi, mabuk dan main perempuan. Bahkan sangat doyan mengganggu istri orang." (Sinden:11).

Data tersebut mempertegas bahwa Rudito sebagai anak seorang lurah yang memiliki watak keras dan aneh. Rudito memiliki kepribadian yang kurang baik karena melakukan perbuatan maksiat. Banyak warga masyarakat yang tidak menyukai sikap Rudito. Perilaku Rudito sebagai putera Lurah Desa Sumberwungu dijadikan alat untuk memicu konflik di masyarakat. Pembunuhan terhadap Rudito dijadikan sumber konflik antara lurah dengan masyarakat dan oknum lain yang ingin menguasai desa Sumberwungu.

Poncodriyo. Poncodriyo adalah Lurah Desa Sumberwungu. Dia adalah pria dewasa yang ambisius dan visioner. Secara denotatif, Poncodriyo adalah tokoh yang mengikuti suatu kelompok dengan paham pemikiran yang sama. Hal tersebut terlihat pada data berikut.

"Poncodriyo sebagai lurah cukup berhasil. Ia dapat menyelesaikan banyak masalah. Perampokan dan pencurian di Sumberwungu jarang terjadi. Hanya akhir-akhir ini terdengat hasutan-hasutan untuk melawan kelompok tertentu. Terhadap hasutan itu Poncodriyo tak banyak bertindak justru ia sering seakan-akan menyuruh rakyatnya melawan kelompok yang tak disukainya." (Sinden:24).

Poncodriyo sebagai sosok pribadi seorang pemimpin desa yang mau bekerja keras dan ambisius. Dalam kepemimpinannya banyak mendapat tantangan dari kelompok orangorang yang tidak menyukainya.

Nyai Estu. Nyai Estu adalah sosok sinden sejati. Jiwanya merupakan sosok sinden tulen. Secara denotatif, Nyai Estu adalah seorang sinden yang mempertahankan nilai tradisi suatu kesenian. Hal tersebut terlihat pada data berikut.

"Estu ingin melahirkan sinden bersuara emas yang kondang. Ia ingin mencetak sinden. ia ingin Tumi menjadi tembang sinden dan mengalahkan semua sinden yang dipersiapkan oleh orang-orang Poncodriyo. Ia ingin berjuang melalui sinden, melalui seoarng anak dara." (Sinden:89).

Nyai Estu sebagai figur seorang wanita yang memiliki cita-cita luhur untuk melestarikan kebudayaan Jawa. Ia sosok pribadi yang mau bekerja keras dan mau melestarikan kehidupan sinden meskipun dalam hal ini, ia harus mengalami banyak tantangan. Nyai Estu juga memahami tentang perkembangan politik lewat kebudayaan yang terjadi di desanya.

Renggo Baskoro. Renggo Baskoro adalah dalang terkenal di Argalaksa. Dia adalah sosok laki-laki wibawa dan disegani oleh orang-orang di sekitarnya. Secara denotatif, Renggo Baskoro adalah pelaku seni dan politik. Hal tersebut terlihat pada data berikut.

"Saya tahu, mas Renggo Baskoro ini telah bekerja keras memulihkan kehidupan kesenian Argalakso yang sempat aut-autan karena diadu domba dan digunakan untuk kepentingan politik khususnya sejumlah oknum partai." (Sinden:20). 
Politik Kebudayaan dalam Novel Sinden Karya Purwadmadi Admadipurwa Kajian Semiotika Roland Barthes (Nuri Dwi Vindriana, Sunarti Mustamar, Sri Mariati)

Renggo Baskoro sebagai sosok pribadi yang menyukai kesenian. Ia sangat peduli dengan kehidupan kesenian di Desa Sumberwungu yang telah rusak karena dipakai untuk peropaganda para politikus. Hal tersebut menunjukkan bahwa kesenian dapat dipakai sebagai alat untuk propaganda partai.

Mangundarma. Mangundarma adalah seorang laki-laki ambisius. Dia merupakan orang kepercayaan Lurah Ponco. Dia membantu Ponco di kelurahan. Mangun tidak mempunyai jabatan tetapi kedekatannya dengan Ponco dalam satu partai menjadikan Mangun sebagai orang kepercayaannya. Mangun diserahi untuk menangani beberapa tugas dan permasalahan desa. Secara denotatif, Mangundarma adalah orang yang dipercaya melakukan kegiatan suatu paham politik. Hal tersebut terlihat pada data berikut.

"Mangundarma memang cerdik. Saat ini dalam posisi menunggu waktu yang tepat... Mangundarma ingin menguasai desa Sumberwungu.” (Sinden:249).

Mangundarma sebagai figur seorang pria yang pandai dan berambisi untuk menguasai desa Sumberwungu.

\section{Konflik}

Konflik menurut Wellek dan Warren (dalam Maslikatin, 2007:56) adalah sesuatu yang dramatik mengacu pada pertarungan antara dua kekuatan yang seimbang dan menyiratkan adanya aksi dan reaksi. Menurut Stanton (dalam Nurgiyantoro, 2000:124) bentuk konflik dibedakan dalam dua kategori: konflik fisik dan konflik batin, konflik eksternal (external conflict) dan konflik internal (internal conflict). Peristiwa yang terjadi pada novel Sinden ditimbulkan oleh konflik yang disebabkan oleh tokoh antargolongan. Hal tersebut merupakan bentuk konflik dalam kategori konflik eksternal. Pada pengertiannya, konflik eksternal adalah konflik yang terjadi antara seorang tokoh dengan sesuatu yang di luar dirinya; lingkungan alam dan lingkungan manusia. Konflik eksternal mengategorikan konflik menjadi dua yaitu konflik fisik dan konflik sosial. Konflik fisik adalah konflik yang disebabkan adanya perbenturan antara tokoh dengan lingkungan alam. Konflik sosial adalah konflik yang disebabkan oleh adanya kontak sosial antarmanusia (Nurgiyantoro, 2000:124).

Konflik dalam novel Sinden muncul dari suatu kasus hilangnya Rudito yang mengakibatkan perselisihan antara Ayah Rudito yaitu Lurah Ponco dengan Ayah Tumi yaitu Karto yang menjadi tersangka hilangnya Rudito. Namun permasalahan ini menyeret beberapa orang dalam dua golongan pro dan kontra.

Kompleksitas konflik yang terjadi di desa Sumberwungu dimaknai sebagai "permasalahan yang berawal dari hilangnya Rudito merupakan permasalahan yang bermuatan politik antar golongan". Hal tersebut dapat dilihat pada data berikut.

"Hmmm," lenguh Ponco. Badannya disandarkan kekursi. Wajahnya tampak sedikit mengendur. "Hilangnya Rudito sudah tak begitu saya pikirkan. Maka kawan-kawan tak perlu terlalu focus pada Rudito. Apalah artinya Rudito disbanding dengan besarnya cita-cita kita mewujudkan kesejahteraan bagi masyarakat Sumberwungu. Pembunuhan dan penghilangan Rudito jangan dipandang sebagai criminal murni. 
Yang jauh lebih besar, justru di situ ada muatan politik, ada tendensi tertentu yang akan digunakan untuk menyerang dan meruntuhkan kewibawaan Ponco lurah. Itu sudah pasti. Target utamanya, melengserkan kedudukanku. Inilah cara Kawankawan saya undang untuk memikirkan suatu serangan balik yang menukik." (Sinden:134-135).

Konflik eksternal terjadi di desa Sumberwungu karena adanya perbedaan pendapat dan perebutan kekuasaan. Para pendukung partai mempergunakan kesenian sebagai alat propaganda untuk mewujudkan keinginannya.

\section{Latar}

Latar atau tempat yang disebut juga sebagai landas tumpu, menyaran pada pengertian tempat, hubungan waktu, dan lingkungan sosial tempat terjadinya peristiwaperistiwa yang diceritakan (Nurgiyantoro, 2000:216). Latar tempat pada novel Sinden: Desa Sumberwungu, rumah Tumi, kantor kelurahan, rumah Nyai Estu, rumah Pak Pancar, dan tobong Misuwur Budaya. Latar waktu pada novel Sinden: masa reformasi, beberapa puluh tahun yang lalu, enam tahun dan enam bulan. Hal tersebut terlihat pada data berikut.

"Sudah lama Gendon tak datang ke kantor kelurahan atau rumah lurah Ponco yang disebelahan dengan balai desa itu. Di seputaran balai desa ini banyak terpampang gambar-gambar raksasa lambing partai. Gambar yang dibuat di atas anyaman bamboo dengan cat putih dan hitam." (Sinden:37).

Latar tempat dan waktu tersebut dapat menunjukkan suasana peristiwa yang terjadi di desa Sumberwungu. Terjadinya konflik tentang perebutan kekuasaan dan perkembangan politik menjadi lebih hidup dengan latar yang tepat.

\section{Analisis Mitos Politik Kebudayaan}

Mitos merupakan salah satu teori semiotika Roland Barthes. Mitos memandang karya sastra dari wacana sosial, konteks kultural, ideologis, dan historis yang direfleksikan dan direduksi menjadi natural atau disampaikan secara terbalik, sebagai bentuk wacana dan ujaran. Mitos memiliki tiga dimensi yaitu penanda, petanda dan tanda. Mitos merupakan bagian dari semiologi. Barthes mengembangkan teori semiologi Ferdinand de Saussure sebagai pembacaan tanda secara tekstual kemudian dilanjutkan dengan pembacaan mitos. Sistem tanda dalam mitos memiliki dua tahapan yaitu sistem tanda pertama dan sistem tanda kedua.

Secara teori, mitos memiliki empat sudut pandang yaitu; mitos adalah sesuatu yang dideterminasi oleh wacana sosial yang merefleksikan sesuatu, mitos terjadi ketika kultur dijungkir balik menjadi yang natural atau ketika kualitas sosial, kultural, ideologis, dan historis terbalik menjadi hal yang natural, mitos kontemporer bersifat diskontinyu tidak hadir dalam bentuk narasi-narasi panjang dengan format baku tetapi hanya dalam bentuk wacana, dan mitos merupakan sebentuk ujaran yang masuk dalam cakupan semiologi (Barthes, 2010:171-172). Mitos bukan hanya berbentuk tuturan oral, melainkan dapat 
Politik Kebudayaan dalam Novel Sinden Karya Purwadmadi Admadipurwa Kajian Semiotika Roland Barthes (Nuri Dwi Vindriana, Sunarti Mustamar, Sri Mariati)

berbentuk tulisan, fotografi, film, laporan ilmiah, olahraga, pertunjukan, iklan, lukisan, dan lain-lain. Mitos pada dasarnya adalah semua yang mempunyai modus representasi (Iswidayati, 2006:5).

Mitos memiliki tiga dimensi yaitu: penanda, petanda dan tanda. Barthes mengatakan bahwa mitos adalah satu sistem khusus, karena dia terbangun dari serangkaian rantai semiologis yang telah ada sebelumnya: mitos adalah sistem semiologis tingkat kedua. Tanda pada sistem pertama, menjadi penanda pada sistem kedua (Barthes, 2004:160-161). Pembacaan mitos pada bab ini akan mereduksi karya sastra menjadi fungsi penandaan seperti pada bagan berikut.

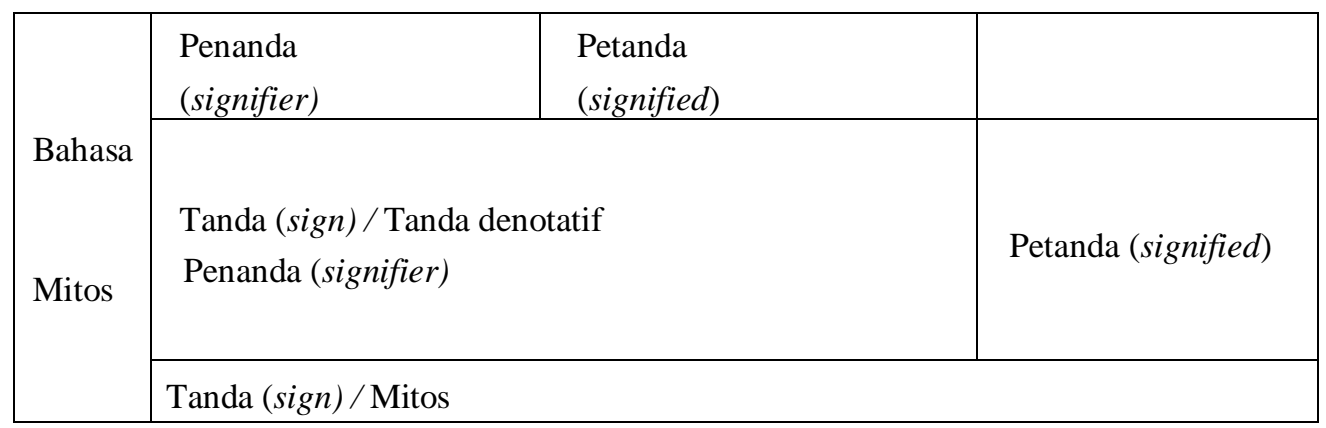

Sistem pertama merupakan pembacaan makna tanda denotatif, bahwa karya sastra merupakan keutuhan cerita berupa narasi yang di dalamnya terdapat tanda-tanda. Tandatanda yang dianalisis menggunakan pembacaan sistem pertama kemudian dilanjutkan dengan pembacaan sistem kedua. Pembacaan sistem kedua melihat mereka (materi-materi wicara) ${ }^{3}$ sebagai bahan mentah (Barthes, 2004:161). Itu artinya, tanda pada sistem pertama akan berubah status menjadi penanda pada sistem kedua kemudian mitos merepresentasikan makna yang mengandung sistem nilai seperti: sejarah, moralitas, politik, budaya dan sebagainya. Pemikiran mitologis Barthes menurut Setiawan (2014:25) mengasumsi peristiwa-peristiwa naratif sebagai peraktik penandaan yang membentuk struktur sebuah karya dan bertujuan menaturalisasi kepentingan politik tertentu.

Analisis sistem pertama menghasilkan tanda sebagai penanda baru pembacaan mitos di sistem kedua. Tokoh-tokoh dalam novel Sinden memiliki karakternya masingmasing. Sistem tanda pertama menghasilkan tanda global yang membedakan tokoh dalam novel mempunyai karakteristiknya masing-masing. Hal tersebut dipengaruhi oleh konsep naratif yang memiliki modus representasi sebagai dasar mitos. Pada novel Sinden, tokoh merepresentasikan perannya sebagai perantara ideologi. Tokoh-tokoh tersebut membentuk aliansi yang dibedakan oleh ideologi dan kekuasaan. Adanya aliansi pada novel Sinden, mengelompokkan tokoh-tokoh tersebut menjadi dua kelompok yaitu: kelompok pro dan kelompok kontra. Pengelompokan tersebut berupa perilaku dan tuntunan moral yang dibedakan oleh ideologi tokoh. Ideologi tersebut menyatukan kelompok dalam menentang

\footnotetext{
${ }^{3}$ Materi-materi wicara mitis adalah bahasa itu sendiri, fotografi, lukisan, poster, ritual, objek-objek, dan yang lainnya (Barthes, 2004:161).
} 
tujuan konsepsi kelompok lain. Hasil pembacaan sistem tanda pertama mengumpulkan data tokoh-tokoh yang terbagi menjadi dua kelompok yaitu kelompok pro dan kelompok kontra.

Tanda-tanda yang dihasilkan merujuk kepada penanda baru pembacaan mitos. Tanda-tanda tersebut adalah: "dengan kegigihan, seorang wanita berhasil menjadi sinden walaupun dihadapkan dengan propaganda kesenian"; "Keresahan dan ketidakpahaman masyarakat terhadap simpang siur permasalahan yang terjadi"; "Orang yang melanggar hukum akan diadili"; dan "Permasalahan yang berawal dari hilangnya Rudito merupakan permasalahan yang bermuatan politik antar golongan". Tanda-tanda tersebut menjadi penanda baru yang menimbulkan mitos tentang pemanfaatan kesenian sebagai media propaganda, suatu hegemoni kebudayaan dan suatu peristiwa yang merefleksikan latar sosial 1965. Hal ini dapat dilihat pada data berikut.

"Sumberwungu dianggap Margono sebagai desa strategis karena kuatnya kehidupan kesenian di desa ini. Disamping itu, desa ini memiliki sejarah panjang sebagai salah satu desa tua di Argalaskasetelah semugih dan sepulur. Desa di mana dilahirkan sinden ternama, tepat dimukim dalang kondang Ki Dipocarito yang sudah diajak ikut emepropogandakan partai. Ketika rombongan ktoprak tobong Misuwur Budoyo akan dikirim bermain di Lapangan Sumberwungu pun atas dasar kesenian Sumberwungu." (Sinden:246).

Submitos latar merepresentasikan bahwa "Desa Sumberwungu merupakan penghasil sinden ternama, didukung dengan kondisi fisiografi dan masyarakat yang masih mempertahankan budaya luhur nenek moyang”. Pembacaan mitos mendapat penekanan pada "kondisi fisiografi dan masyarakat yang masih menjaga pelestarian budaya". Hal tersebut melatarbelakangi peristiwa konflik di desa Sumberwungu karena kepentingan suatu golongan untuk menguasai tempat tersebut.

Peristiwa yang terjadi di desa Sumberwungu adalah bagian dari tragedi nasional. Peristiwa tersebut terjadi dalam waktu yang panjang bahwa latar waktu pada novel Sinden merupakan "suatu peristiwa yang saling berkaitan selama berpuluh-puluh tahun". Novel Sinden dibagi menjadi tiga bagian yaitu: prolog, isi dan epilog.

Latar waktu pada bagian prolog menunjukkan tanda waktu peristiwa tersebut terjadi pada "masa reformasi". Bagian isi, yaitu Bab 1 sampai dengan Bab 13 merupakan peristiwa yang terjadi di Sumberwungu "beberapa puluh tahun sebelum masa reformasi", kemudian pada bab empat belas merupakan peristiwa yang terjadi "enam tahun setelah peristiwa di desa Sumberwungu berangsur redam”. Pada bagian epilog menunjukkan peristiwa waktu "ketika Tumi telah mengandung selama dua bulan".

Masa Reformasi terjadi pada pertengahan tahun 1998 yaitu masa ketika presiden Suharto mengundurkan diri sebagai kepala negara kemudian digantikan oleh wakilnya. Adegan yang dimunculkan pada bab prolog adalah berita hilangnya Tuwuh sebagai seorang penyair yang berpengaruh dalam aktivitasnya memimpin massa berdemo. Peristiwa tersebut merupakan refleksi dari peristiwa di Indonesia bahwa terjadi peristiwa yang sama ketika masa Reformasi di Indonesia terjadi tragedi baku tembak dengan mahasiswa untuk menurunkan jabatan Suharto sebagai presiden. Hal ini dapat dilihat pada data berikut. 
Politik Kebudayaan dalam Novel Sinden Karya Purwadmadi Admadipurwa Kajian Semiotika Roland Barthes (Nuri Dwi Vindriana, Sunarti Mustamar, Sri Mariati)

"Beberapa hari lalu, telah terjadi pergolakan di Jakarta. Seperti sudah disiarkan radio republic, semua sudah bias ditumpas. Tentara diminta melakukan pengamanan. Semua kegiatan kita hentikan, kita jaga,. Para dalang dan pelaku kekacauan sedang diburu tentara. Oleh sebab itu, kita harus bikin tenang. Kita tidak tahu siapa kawan, siapa lawan. Tentara akan menjagasuoaya kekacauan tidak meluas. Masyarakat harap tenang. Seperti yang kita tahu, rentetan peristiwanya sudah sudah merembet ke daerah kita." (Sinden:258).

Penanda untuk menunjukkan bahwa beberapa puluh tahun yang ditunjukkan pada Bab 1 sampai dengan Bab 13 menjadi kuat bahwa peristiwa di desa Sumberwungu merupakan peristiwa pada masa orde lama, ketika sentralisasi negara berada pada pemerintahan Sukarno. Hal tersebut ditunjukkan dengan penanda waktu pada Bab 14 yang menunjukkan waktu enam tahun setelah pergantian pemerintahan baru. Pergantian antara masa pemerintahan Sukarno ke pemerintahan Suharto atau masa orde lama ke masa orde baru. Indonesia mengalami dua pergantian pemerintahan sebelum masa reformasi.

Peristiwa tempat dan waktu merefleksikan adanya mitos dalam novel Sinden adalah peristiwa nasional yang terjadi pada masa orde lama sampai masa reformasi.

\section{SIMPULAN}

Berdasarkan analisis data dengan menggunakan konsep mitos Roland Barthes, hasil pembacaan sistem tanda pertama direduksi menjadi fungsi penanda sistem tanda kedua. Sistem tanda kedua mendeskripsikan pemaknaan mitos yang terbentuk dalam tanda-tanda dari hasil sistem tanda pertama yang saling berkaitan. Pembacaan sistem tanda kedua menghasilkan mitos wacana politik kebudayaan yang muncul dari konsep peristiwaperistiwa yang terjadi di suatu daerah kecil bernama Sumberwungu. Masyarakat yang tinggal di daerah tersebut mengalami permasalahan yang kompleks. Kompleksitas permasalahan muncul secara individu, golongan, sosial dan ideologis yang dihadapkan dengan sistem peralihan pemerintahan. Narasi yang ada di dalam novel Sinden menjelaskan nilai ideologis kesenian dari dua golongan kesenian yang membentuk aliansi dengan masing-masing kepentingan ideologis. Ideologi tersebut berubah menjadi suatu gerakan melalui kesenian sebagai sarana penyampaian yang menjadikan masyarakat (pelaku seni atau penikmat seni) sebagai subyek sasaran. Proses pembentukan kebudayaan terjadi ketika ideologi tersebut mampu menguasai dan mendominasi kultur di suatu daerah. Sumberwungu merupakan konsep yang menjadi bagian kecil dari dampak peristiwa nasional.

Novel Sinden merefleksikan peristiwa-peristiwa yang terjadi di Indonesia pada masa orde lama, orde baru dan reformasi. Latar waktu pada masa orde lama lebih banyak mendapatkan porsi di dalam narasi novel. Perdebatan ideologi yang dipengaruhi oleh suasana politik mendesak kesenian mempropagandakan tema-tema pertunjukan yang mewakili misi-misi suatu golongan. Ideologi dari masing-masing aliansi mewakili kelompok-kelompok kesenian yang hidup pada masa orde lama. "seni untuk seni" dan "seni untuk rakyat" merupakan ideologi yang menjadi perdebatan kelompok kesenian pada 
tahun 1960-an. Suatu organisasi bernama Lekra menjadikan "seni untuk rakyat" sebagai asas bekesenian dengan tujuan mejadikan kesenian sebagai media penyadaran masyarakat tentang dampak feodalisme dan imperialisme yang merugikan masyarakat cilik. "seni untuk seni" merupakan tandingan yang dipakai oleh Manikebu dalam surat pernyataan gelanggang yang menyampaikan bahwa kesenian harus kembali kepada fungsinya sebagai kesenian.

Analisis menggunakan konsep mitologi Roland Barthes dapat menunjukkan motivasi yang dituturkan dalam teks sehingga wacana sosial, konteks kultural, sosial, ideologis, dan historis dapat dilacak menjadi pengetahuan dan sejarah yang ditangkap oleh penelitian ini. Kekacauan yang terjadi pada masa orde lama sampai masa reformasi, secara histori kekuasaan di Indonesia mempunyai pengaruh besar terhadap kesenian. Pemerintah ikut serta dalam hal tema pertunjukan sampai mengontrol organisasi kelompok kesenian sehingga kesenian menjadi salah satu unsur kebudayaan yang berkembang mengikuti perkembangan politik pemerintahan.

\section{DAFTAR PUSTAKA}

Admadipurwa, P. 2007. Sinden. Yogyakarta: Navila.

Barthes, R. 1990. Image/Music/Text;Essay. London: Fortana Press. Terjemahan oleh A. Hartono. 2010. Imaji/Musik/Teks. Yogyakarta: Jalasutra.

Barthes, R. 2004. Mythologies. Terjemahan oleh Nurhadi dan A. Sihabul Millah. Mitologi. Yogyakarta: Kreasi Wacana.

Faruk. 2012. Metode Penelitian Sastra. Yogyakarta: Pustaka Pelajar.

Hoed, B. H. 2014. Semiotik dan Dinamika Sosial Budaya. Depok: Komunitas Bambu.

Iswidayati, S. 2006. "Roland Barthes dan Mithologi." Imajinasi 2(2). Universitas Negeri Semarang.

Maslikatin, T. 2007. Kajian Sastra: Prosa, Puisi, Drama. Jember: UNEJ Press.

Nurgiyantoro, B. 2000. Teori Pengkajian Fiksi. Yogyakarta: Gadjah Mada University Press.

Pradopo, R. D. 2003. Dewa Telah Mati: Kajian Strukturalisme-Semiotik. Editor Jabrohim. Yogyakarta: PT Hanindita Graha Widya.

Setiawan, I. 2014. "Eksnominasi Politik dalam Narasi: Konseptualisasi Mitologis Roland Barthes dan Implikasi Metodologisnya dalam Kajian Sastra. Jentera 3(10):23 - 35. 